UDC: 004:378

DOI: https://doi.org/10.24195/2414-4665-2017-6-11

Liudmyla Matviichuk,

PhD (Candidate of Ppedagogical Sciences), associate professor, Department of Computer Science,

Chernihiv National T. G. Shevchenko Pedagogical University, 53, Hetmana Polubotka Str., Chenihiv, Ukraine,

Liudmyla Kukhar,

PhD (Candidate of Pedagogical Sciences), associate professor, Department of Computer Engineering and Educational Explorations, National Pedagogical Dragomanov University, 9, Pyrohova Str., Kyiv, Ukraine,

Hnedko Nataliia,

PhD (Candidate of Pedagogical Sciences), associate professor, Department of ICT and Methods of Teaching Informatics, Rivne State University of Humanities, 12, Stepana Bandery Str., Rivne, Ukraine

\title{
EXAMINING FACTORS OF USING INFORMATION AND COMMUNICATION TECHNOLOGIES FOR E-LEARNING ORGANIZATION
}

In the time when information and communication technologies (ICT) are considered to be the significant tool in education, there arises a question if there are proper conditions of their implementation for e-learning organization at higher educational institutions in Ukraine. The paper aims to examine teachers' ICT skills and factors which slow down the process of using ICT for teaching students. The survey involved 106 teachers working at Ukrainian educational institutions of various types. The following questionnaires were used in the survey: "Students' Impressions Scale", "Teachers' Attitude Towards Elearning Checklist", "Factors Affecting ICT Use", "Educational Institutions Provision Quality". The questionnaires consisted of closed-and open-ended questions, as well as scale questions. Accrding to the research outcomes, the following factors positively influence the use of ICT for e-learning organization: self-fulfillment, students' interest and motivation, financial gain, administration's and colleagues' respect, personal interest, improvement of academic performance. The most significant factors negatively affecting the process of ICT application are as follows: low level of equippment support, improper facilities, insufficient financial support, lack of software, lack of time, teachers' incompetence. Despite the low level of Ukrainian educational institutions' innovative activity assurance, teachers do their best to implement ICT into the educational process and make it more interesting for students. The insufficient level of soft- and hardware supply, the lack of powerful computers, poor financial support, personal factors, technical incompetence of teachers, and lots of other challenges should be urgently solved in order to provide Ukrainian students with high-quality education.

Keywords: e-learning, ICT, innovative activity, teachers, factors, difficulties, challenges.

\section{Introduction}

The education informatization requires the educational process participants immerse into the environment where new tools, techniques and platforms for education management are being created, developed and implemented. E-learning becomes more and more popular in the education systems all over the world, which is suggested to be applied together with traditional forms of teaching. There is no doubt that e-learning helps to solve a number of pedagogical challenges, as it creates favorable educational environment, providing students with the opportunity to use educational materials whenever and wherever they need them.

The education modernization should involve purposeful application of ICT, enriching the educational process with e-learning tools, etc. This issue is covered in a number of state documents: "Regulation on e-learning" (\#1060 dated October, 1, 2012), Law of Ministry of Education and Science of Ukraine (\#466 dated April, 25, 2013), "National strategy of education development in Ukraine for 2012-2021" (dated 2013), as well as the EU program "2020 Horizon" (dated 2014). These documents imply the improvement of education quality, soft- and hardware provision, and mainly the improvement of the level of e-learning in Ukraine.

Taking into account the need for renewal/modernization of higher education, the issues of the level of higher educational institutions' financial and logistical support, gradual implementation of ICT into the educational process, etc. are considered to be relevant today [12].

The issue of using ICT has been studied by many scientists, for example, V. Bykov, R. Hurevych, M. Zhaldak, L. Lisina [10], O. Spivakovskyi, Ya. Yakunin [14]. N. Ignatova, V. Dagiené, \& S. Kubilinskiené [3] specify that students' academic progress would be better if they perform tasks on the basis of ICT. Thus, it is reasonable to encourage teachers to use ICT at their lessons. Some scientists [6;4] investigated teachers' attitude towards ICT, as well as the factors influencing ICT integration in the educational environment $[1,9]$. The works of S. Mumtaz [5], M. Salima [7], A. Toter [8] deal with 
teachers' attitude towards ICT as an efficient teaching method. Indian researchers E. Goyal, S. Purohit, \& M. Bhagat examined factors influencing the use of ICT in the management education, and they have come to the conclusion about the discrepancy between expectations and real satisfaction with current use of ICT [2, p. 42]. S. Ivanov, L. Kramer, D. Morrison studied the peculiarities of using e-leaning in the educational process.

However, the scientific literature review and our own experience of the educational process organization by means of ICT [11] lead to the conclusion that the issues of ICT availability in educational institutions of Ukraine, as well as factors slowing down the ICT implementation into the educational process based on e-learning still remain understudied. That is why it is relevant and needs further investigation.

The paper aims to examine teachers' ICT competency, and well as reveal factors negatively affecting the implementation of ICT into the educational process.

\section{Research methods}

The study was performed using both theoretical and empirical research methods: generalization and summing up of scientific literature on the issue of e-learning, induction; observation, surveying. The following questionnaires were used in the survey: "Students' Impressions Scale", "Teachers' Attitude Towards E-learning Checklist", "Factors Affecting ICT Use", "Educational Institutions Provision Quality". The questionnaires consisted of closed- and open-ended questions, as well as scale questions.

The survey involved teaching staff $(7,5 \%$ professors, $34 \%$ associate professors, $25.5 \%$ senior lecturers, $23.6 \%$ university lecturers, $7.5 \%$ school teachers, $1.9 \%$ postgraduate students) of Ukrainian educational institutions of various types $(n=106)$. The questionnaires were sent to the respondents via e-mails, Facebook, LinkedIn, Twitter, Google+.

\section{Research results}

There are a great number of ICT tools promoting the efficient organization of e-learning, for instance, internet in general, as well as e-learning platforms, web-services, video lessons, multimedia presentations, testing systems, e-journals, etc.

The successful implementation of e-learning depends on a number of factors, including motivating educational process participants. E-learning should be applied as the alternative to traditional methods, or as a combination of traditional and innovative forms, which is so-called blended learning.

There are lots of online universities where one can get access to the learning materials though unfortunately not all resources are available for ordinary users, who are not taking their course. European countries have great experience in this field, and there are a number of massive open online courses (MOOC) there [13].

It is reasonable to consider the availability of elearning and conditions for innovative activity organization in educational institutions. The aim of e-learning is to fill in the gaps in students' knowledge, which arise by a number of reasons (for example, a student misses classes when he/she finds a job). In most cases, e-learning is used as an alternative to traditional studying. For example, in Chernihiv National T. G. Shevchenko Pedagogical University, practical training on "ICT in Education and Science" for master-degree students was carried out by means of e-learning because most of students were employed or were working on their second degree abroad.

The first lesson was conducted in a traditional form: a teacher provided students with information about necessary and available e-resources (data is collected on the website

https://sites.google.com/site/navcalnapraktikakitvoin, where one can find necessary information about practical training, including academic performance e-journal). Further lessons were conducted in the forms of an online course. Throughout the whole period of learning the students sent the completed tasks to a teacher to check. At the last lesson they presented their projects. After taking the course, the students were suggested to fill in the questionnaire and assess the educational process. According to the results, all the respondents positively evaluated it and considered e-learning to be a great alternative to the traditional methods.

Using checklists, we tried to find out the availability and popularity of e-learning among Ukrainian educational institutions teachers. According to the results, $68.4 \%$ of the respondents use e-learning elements in their work. The questionnaire also included a question if the university (where a respondent works) provides students with an opportunity to take online course, and $89.5 \%$ positively replied to it. Probably the respondents distinguish the terms "e-learning" and "online course", though they are used as synonyms and mean the same thing. Also the survey results processing has shown that Moodle (47.8\%), Eliademy $-13 \%$, Edmodo $-8.7 \%$ are the most popular services for e-learning organization with the respondents. Google Classroom, Canvas, Nel LMS, Canvas, Easygenerator are less popular ones (though they have some technical advantages). Besides, it has been found that $52.6 \%$ of the teachers participate in mutual filling of the websites with content together with their colleagues.

The teachers were asked to assess 12 online course services according to 5-point scale (5 - very good, 4 good, 3 - satisfactory, 2 - bad, 1 - undecided/a respondent knows nothing about the service). Table 1 presents the results of services assessment. 
Table 1.

Evaluation of services used to create online courses (\%)

\begin{tabular}{|c|c|c|c|c|c|c|c|c|c|c|c|c|}
\hline & $\begin{array}{l}\frac{0}{z} \\
\stackrel{8}{8} \\
\sum\end{array}$ & 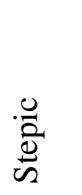 & 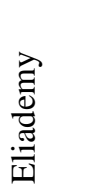 & $\begin{array}{l}8 \\
8 \\
0 \\
\text { g }\end{array}$ & ڤัٌ & $\begin{array}{l}\stackrel{n}{0} \\
\stackrel{0}{0} \\
0 \\
0\end{array}$ & 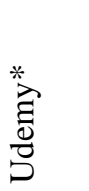 & 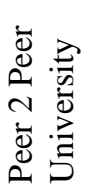 & 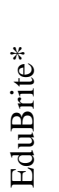 & 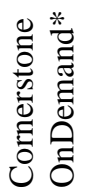 & $\begin{array}{l}\frac{*}{\tilde{E}} \\
\text { 苞 } \\
>\end{array}$ & 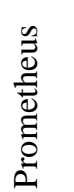 \\
\hline Very good & 16 & 11 & & & & & & & & & & \\
\hline Good & 37 & 10.1 & 26.4 & 21.1 & 15.8 & 21.1 & 10.5 & 15.8 & 21 & 21 & 15.8 & 12.5 \\
\hline Satisfactory & 37 & 42.1 & 36.8 & 36.8 & 47.4 & 42.1 & 47.4 & 47.4 & 42 & 36.9 & 42.1 & 12.5 \\
\hline Bad & 5 & & & 5.3 & & & & & & 5.3 & 5.3 & \\
\hline Undecided & 5 & 36.8 & 36.8 & 36.8 & 36.8 & 36.8 & 42.1 & 36.8 & 37 & 36.8 & 36.8 & 75 \\
\hline
\end{tabular}

*shareware program which includes billing plans.

The survey has shown that the respondents prefer Moodle, Stepic, and Eliademy. These platforms are free and have the function package necessary for e-learning (MOOC format support, registration via social networks, etc.).

The research outcomes lead to the conclusion that despite constant focus on the low level of Ukrainian teachers' innovative work, in very deed they use elearning tools in their teaching practice. Most of the respondents are familiar with the platforms serving for online courses creation, and can create their own ones, take part in filling the websites with necessary content, etc. This means that e-learning in our country is quite available (at least teachers have the desire and skills of using it in their work). But there arises the following question: are educational institutions provided with necessary conditions for that? The teaching staff is ready for applying e-learning tools in the educational process, but are the establishments? It should be found out.
The next step of our research is determining the factors affecting the application of ICT for e-learning organization. By means of the survey we have found both internal and external factors playing a great role in teachers' work. The internal ones include available conditions for e-learning implementation, teacher's satisfaction with the lesson conducted, his/her experience enrichment, benefits of using innovations, recognition of teacher's professional competence by students. The external ones involve the assessment of material benefits of the work, status in a team, wage increase, etc. These factors are interrelated and as a rule they work altogether.

In order to provide efficient work for teachers' selffulfillment it is necessary to create well-balanced conditions (material, financial, organizational, informational, psychological, motivational, etc.). Every respondent evaluated the quality of conditions for e-learning application in the institution where he/she works, according to 3-point scale (3 - great, 2 - good, 1 - satisfactory, 0 - unsatisfactory). The research outcomes are presented in Fig. 1.

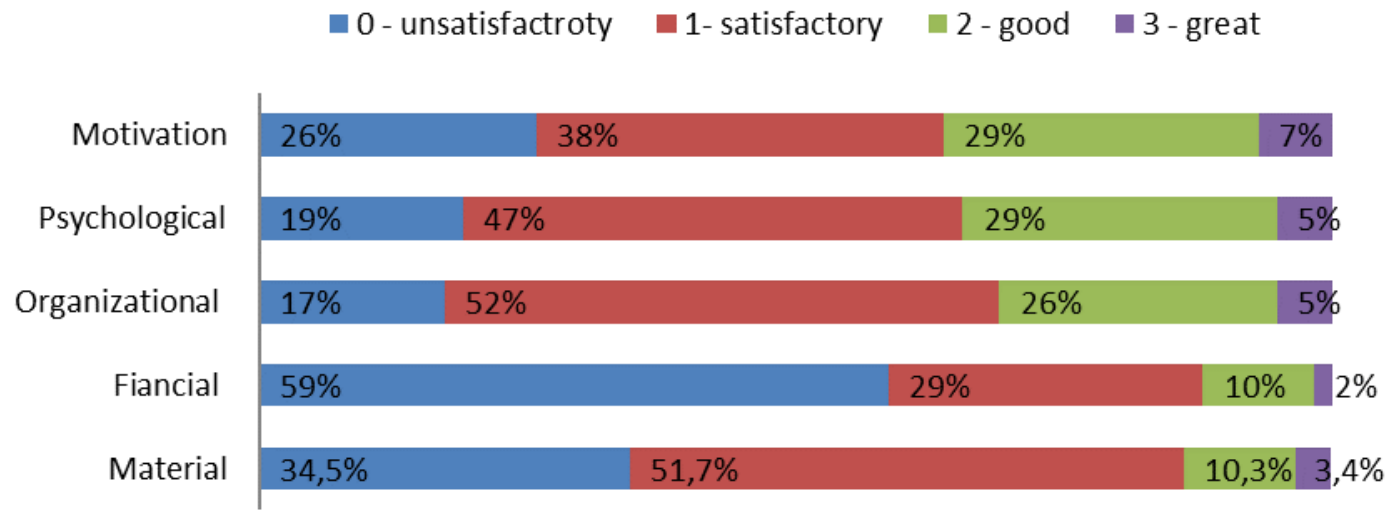

Fig. 1. Quality of conditions for e-learning implementation

Thus, according to the results, $59 \%$ of the respondents assessed the financial conditions as unsatisfactory. The state of material and organizational conditions is quite satisfactory (as assessed by $51.7 \%$ and $52 \%$ of the respondents correspondingly). Psychological and motivation conditions were evaluated identically (as satisfactory) by the greatest number of the respondents: $47 \%$ and $38 \%$ correspondingly. The mean value of the conditions quality assurance was $4.5 \%$. The research outcomes indicate the shortcomings in the educational administrations' work and the low level of conditions provided for e-learning application. 
The difficulties teachers face in their work when implementing innovations should be also discussed. According to the results of the carried out survey, the main challenges are as follows: resources limitedness (PC, multimedia equipment); absence of a mechanism of innovations implementation; lack of time; lack of colleagues' and administration's support; lack of motivation; conservatism in education; absence of learning and teaching support; teachers' psychological unreadiness and lack of necessary knowledge, etc. All these challenges should be addressed by institution administration because it is administration who should provide the educational process with all necessary requirements and conditions.
The respondents have selected the following positive factors influencing the use of ICT for e-learning organization:

- $\quad$ self-fulfillment $-69.6 \%$;

- students' interest and motivation $-53.6 \%$;

- financial gain $-12.5 \%$;

- administration's and colleagues' respect $-10.7 \%$;

- personal interest - $1.8 \%$;

- improvement of academic performance $-1.8 \%$.

Having studied the factors influencing the use of ICT we asked the respondents to arrange them into groups and assess them according to the 4-point scale (4 - very important, 3 -important, 2 - neutral, 3 - not important). The results are presented in Fig. 2.

- Very important $\%$ Important Not imortant $\equiv$ Neutral

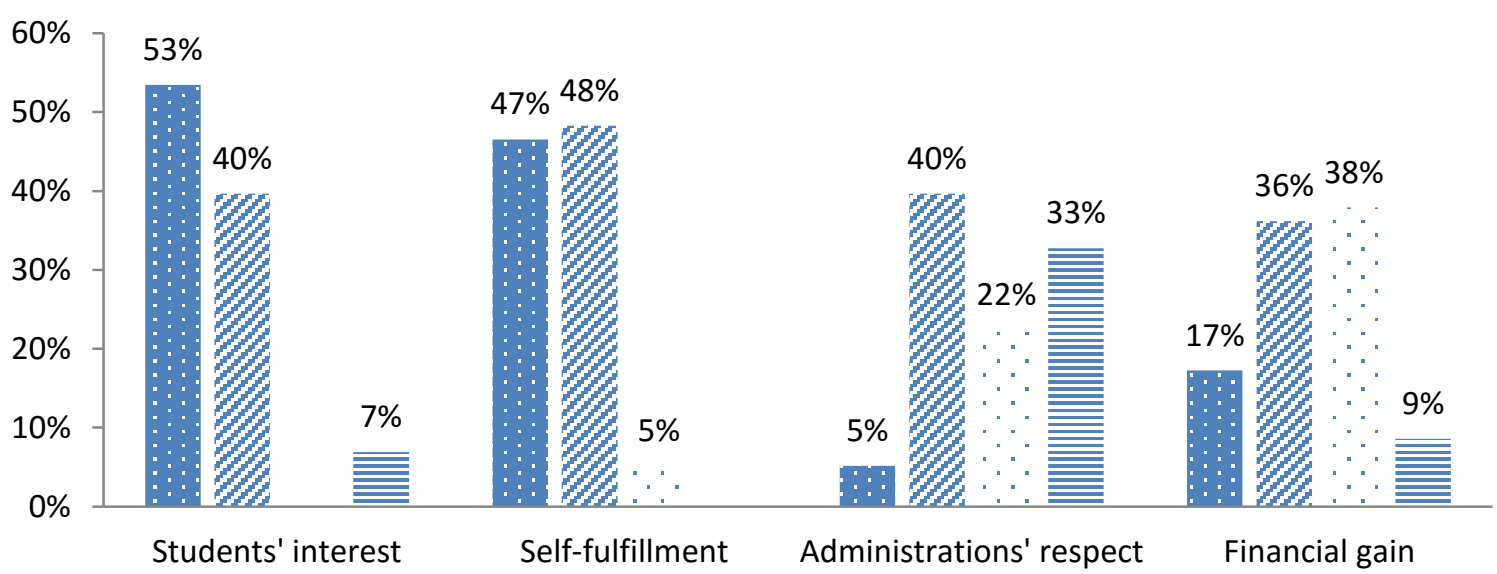

Fig. 2. Factors motivating teachers to use ICT in their work

Thus, as we can see, the internal motivation prevails. The teachers do their best to provide innovations in education, make the educational process interesting to motivate students to learn. According to the results, $81.8 \%$ are not satisfied with the conditions for ICT implementation but they try to cope with the challenge themselves in the following ways: by taking own initiative $(82.8 \%)$, by taking advanced training $(48.3 \%)$, by attending their colleagues' lessons $(12.1 \%)$, working with methodical literature $(10.3 \%)$, etc.

The most significant factors negatively affecting the process of ICT application are as follows:

- low level of equippment support (only $11.3 \%$ are equipped with computers; $35.9 \%$ out of these $11 \%$ are supplied with high-power computers, and $50.9 \%$ of them have internet access);

- improper facilities (only $28.3 \%$ of classrooms are provided with posters, models, wall units, etc.);

- insufficient financial support (the significance of material stimulus, benefits $-58 \%$, discontent with salary $-69.8 \%)$;

- lack of software $-41.5 \%$;

- lack of time (for creating and implementing ICT into the educational process $-62.3 \%$ );
- teachers' incompetence.

\section{Conclusions}

Summing up it should be noted that despite the low level of Ukrainian educational institutions' innovative activity assurance, teachers do their best to implement ICT into the educational process and make it more interesting for students. The insufficient level of soft- and hardware supply, the lack of powerful computers, poor financial support, personal factors, technical incompetence of teachers, and lots of other challenges should be urgently solved in order to provide Ukrainian students with high-quality education.

Thus, in order to improve the unsatisfactory level of e-learning at educational institutions of Ukraine, it is necessary to renew the software and hardware supply (equipping classrooms with modern powerful devices), improve the financial support (increasing teachers' salaries, providing them with benefits, etc.); fill the information provison with e-learning recourses, e-books, etc.; allocate time for teachers to deal with innovative activities; increase the level of teachers' ICT skills; create systems of encouraging teachers to deal with ICT, etc.

The research outcomes prove the necessity of further development of e-learning resources for e-learning support. 


\section{REFERENCES}

1. Bozdogan, D., \& Özen, R. (2014). Use of ICT Technologies and Factors Affecting Pre-Service ELT Teachers' Perceived ICT Self-Efficacy. Turkish Online Journal of Educational Technology, 13(2), 186-196 [in English].

2. Goyal, E., Purohit, S., \& Bhagat, M. (2010). Factors that affect information and communication technology usage: A case study in Management Education. Journal of Information Technology Management, 11 (4), 38-57 [in English].

3. Ignatova, N., Dagienè, V., \& Kubilinskienè, S. (2015). ICT-based Learning Personalization Affordance in the Context of Implementation of Constructionist Learning Activities. Informatics in Education. 14 (1), 51-65 [in English].

4. Igwe Sylvester Agbo. (2015). Factors Influencing the Use of Information and Communication Technology (ICT) in Teaching and Learning Computer Studies in Ohaukwu Local Government Area of Ebonyi State-Nigeria. Journal of Education and Practice. 6 (7), 71-86 [in English].

5. Mumtaz, S. (2000). Factors Affecting Teachers' Use of Information and Communications Technology: a review of the literature. Journal of Information Technology for Teacher Education, 9 (3), 319-342.

6. Player-Koro, C. (2012). Factors Influencing Teachers' Use of ICT in Education. Education Inquiry. 3 (1), 93-108 [in English].

7. Sallimah, M. S., Kumar L. (2014). Investigating the factors influencing teachers' use of ICT in teaching in Bruneian secondary schools. Education and Information Technologies, 19 (4), 747-762 [in English].

8. Totter, A., Stütz, D., \& Grote, G. (2006). ICT and Schools: Identification of Factors Influencing the use of new Media in Vocational Training Schools. The Electronic Journal of e-Learning, 4 (1), 96-103 [in English].

9. Vitanova, V., Atanasova-Pachemska, T., Ilievc, D., \& Pachemskad, S. (2015). Factors Affecting the De-

\section{ЛIТЕРАТУРА}

1. Bozdogan, D. Use of ICT Technologies and Factors Affecting Pre-Service ELT Teachers' Perceived ICT SelfEfficacy / D. Bozdogan \& R. Özen // Turkish Online Journal of Educational Technology. - 2014. - №13(2). - C. 186-196.

2. Goyal E. Factors that affect information and communication technology usage: A case study in Management Education / E. Goyal, S. Purohit, \& M. Bhagat // Journal of Information Technology Management. - 2010. - №11 (4). - C. 38-57.

3. Ignatova N. ICT-based Learning Personalization Affordance in the Context of Implementation of Constructionist Learning Activities / N. Ignatova, V. Dagienè, \& S. Kubilinskienè // Informatics in Education. - 2015. №14 (1). - C. 51-65.

4. Igwe Sylvester Agbo. Factors Influencing the Use of Information and Communication Technology (ICT) in Teaching and Learning Computer Studies in Ohaukwu Local Government Area of Ebonyi StateNigeria / Agbo Igwe Sylvester // Journal of Education and Practice. - 2015. - №6 (7). - C. 71-86. velopment of ICT Competencies of Teachers in Primary Schools. Procedia - Social and Behavioral Sciences, 191 (2), 1087-1094 [in English].

10. Lisina L. O. (2016). Vplyv informatyzatsii osvity na transformatsiiu tekhnolohii navchannia $\mathrm{u}$ vyshchii shkoli [Impact of education informatization aimed at teaching techniques transformation in higher education]. Pedahohika formuvannia tvorchoi osobystosti u vyshchii $i$ zahalnoosvitnii shkolakh - Pedagogy of creative personality formation in higher and secondary education, 50, 425-432. Retrieved from: http://nbuv. gov. ua/UJRN/Pfto_2016_50_57 [in Ukrainian].

11. Matviichuk L. A. (2016). Orhanizatsiia samostiinoi roboty studentiv vyshchykh navchalnykh zakladiv za dopomohoiu informatsiino-komunikatsiinykh tekhnolohii [University students' self-study organization by means of ICT]. Europe Humanities Studies: Education and Training, 2, 335-345 [in Ukrainian].

12. Nakaz Pro Natsionalnu stratehiiu rozvytku osvity $v$ Ukraini na period do 2021 roku [Order on National Strategy for education development till 2021]. Retrirved from: http://zakon2.rada.gov.ua/laws/show/344/2013 [in Ukrainian].

13. Sedmoy prognoz iz otcheta Bersin by Deloitte «Predictions for 2016»: revoliutsyia v korporativnom obuchenii [The 7th prognosis from Bersin by Deloitte "Predictions for 2016" report": revolution in corporate education].

Retrieved http://hrdocs.ru/novosti/bersin-7 [in Russian].

14. Yakunin, Ya. Yu. (2013). Limituiuchy faktory optymalnoho vykorystannia IKT na suchasnomu urotsi [Limitation factors of optimal use of ICT at a modern lesson]. Naukovyi chasopys NPU imeni MP Drahomanova - Newsletter of National Dragomanov Pedagogical University, 19 (29), 198-201 [in Ukrainian].

5. Mumtaz S. Factors Affecting Teachers' Use of Information and Communications Technology: a review of the literature / S. Mumtaz // Journal of Information Technology for Teacher Education. - 2000. - №9 (3). - C. 319-342.

6. Player-Koro C. Factors Influencing Teachers' Use of ICT in Education / C. Player-Koro // Education Inquiry. - 2012. - №3 (1). - C. 93-108.

7. Sallimah M. S. Investigating the factors influencing teachers' use of ICT in teaching in Bruneian secondary schools / M. S. Sallimah, L. Kumar // Education and Information Technologies. - 2014. - №19 (4). - C. 747-762.

8. Totter A. ICT and Schools: Identification of Factors Influencing the use of new Media in Vocational Training Schools / A. Totter, D. Stütz, \& G. Grote // The Electronic Journal of e-Learning. - 2006. - №4 (1). - C. 96-103.

9. Vitanova V. Factors Affecting the Development of ICT Competencies of Teachers in Primary Schools / V. Vitanova, T. Atanasova-Pachemska, D. Ilievc, \& S. Pachemskad // Procedia - Social and Behavioral Sciences. - 2015. - №191 (2). - C. 1087-1094. 
10. Лісіна Л. О. Вплив інформатизації освіти на трансформацію технології навчання у вищій школі / Л. О. Лісіна // Педагогіка формування творчої особистості у вищій і загальноосвітній школах. - 2016. Вип. 50. - С. 425-432. - Режим доступу: http://nbuv. gov. ua/UJRN/Pfto_2016_50_57.

11. Матвійчук Л. А. Організація самостійної роботи студентів вищих навчальних закладів за допомогою інформаційно-комунікаційних технологій / Л. А. Матвійчук // Europe Humanities Studies: Education and Training. - 2016. - №2. - C. 335-345.
12. Наказ Про Національну стратегію розвитку освіти в Україні на період до 2021 року. - Режим доступу: http://zakon2.rada.gov.ua/laws/show/344/2013.

13. Седьмой прогноз из отчета Bersin by Deloitte «Predictions for 2016»: революция в корпоративном обучении [Электронный ресурс] // HRdocs : [полноформат. HR-б-ка]. - Электрон. данные. - Москва, 2013-2016. - Режим доступа: http://hrdocs.ru/novosti/bersin-7.

14. Якунін Я. Ю. Лімітуючи фактори оптимального використання IKT на сучасному уроці / Я. Ю. Якунін // Науковий часопис НПУ імені МП Драгоманова. - 2013. - №19 (29). - С. 198-201.

\section{Людмила Анатолї̈вна Матвійчук, кандидат педагогічних наук, доиент кафедри інформатики і обчислювальної техніки, Чернігівський національний педагогічний університет імені Т.Г. Шевченка, вул. Гетьмана Полуботка 53, м. Чернігів, Украӥна, \\ Людмила Олександрівна Кухар, кандидат педагогічних наук, доцент кафедри комп 'ютерної інженерії і освітніх вимірювань, Національний педагогічний університет імені М.П. Драгоманова, вул. Пирогова 9, м. Київ, Україна, \\ Наталія Михайлівна Гнедко, кандидат педагогічних наук, доиент кафедри інформаційно-комунікаційних технологій і методики викладання інформатики, Рівненський державний гуманітарний університет, вул. Степана Бандери 12, м. Рівне, Україна}

\section{ДОСЛІДЖЕННЯ ФАКТОРІВ ЗАСТОСУВАННЯ ІНФОРМАЦЙНО-КОМУНІКАЦІЙНИХ ТЕХНОЛОГІЙ ДЛЯ ОРГАНІЗАЦІЇ ЕЛЕКТРОННОГО НАВЧАННЯ}

В той час, коли інформаційно-комунікаційні технології визнані як вагомий інструмент в реалізації системи освіти, виникає питання: чи забезпечені навчальні заклади належними умовами їх застосування для організації електронного навчання (е-навчання). Мета статті полягає у визначенні готовності викладачів до е-навчання та з'ясування факторів гальмування процесу використання інформаційно-комунікаційних технологій (IКТ) у навчанні. Під час дослідження використано теоретичні та емпіричні методи: узагальнення, індукція, спостереження, опитування. У результаті дослідження розкрито стан забезпечення умов та труднощі, які перешкоджають інноваційній діяльності. Також окреслено коло позитивних чинників, які всупереч всьому, стимулюють викладачів використовувати елементи е-навчання. 3'ясовано стан готовності навчальних закладів України до інноваційної діяльності, який перебуває на вкрай низькому рівні та потребує вдосконалення, оновлення. Відсутність належного рівня програмноготехнічного забезпечення, нестача швидкісних комп'ютерів, мале фінансове забезпечення, брак часу на інтеграції ІКТ в навчальне середовище, особисті чинники, технічна некомпетентність викладачів, відсутність підтримки з боку адміністрації ВНЗ - усі ці проблеми потребують якомога швидшого вирішення. В цілому отримані результати ще раз акцентують увагу на низькому рівні інформатизації освіти. Для поліпшення незадовільного стану інноваційної діяльності у навчальних закладах адміністрації потрібно оновити програмно-технічне забезпечення (оснащення аудиторій всіма необхідними сучасними, швидкісними, багатофункціональними пристроями); підвищити фінансове забезпечення (підняття заробітної плати, виплачування надбавок за престижність педагогічної праці); здійснювати наповнення інформаційного забезпечення (електронними навчальними ресурсами, електронними навчально-методичними комплексами тощо); вивільнити час викладачам для інноваційної діяльності, підвищити рівень ІКТ-компетенції викладачів; створити систему мотивації, заохочення до інноваційної діяльності. Все це дасть можливість реалізуватися як студентам, так і викладачам.

Ключові слова: е-навчання, ІКТ, інноваційна діяльність, викладачі, фактори, труднощі нововведень.

Reviewed by Doctor of Pedagogy, prof. Yu. Horoshko 